\title{
EVALUATION OF GENOTYPE BY ENVIRONMENT INTERACTION FOR GRAIN YIELD IN DURUM WHEAT USING NON-PARAMETRIC STABILITY STATISTICS
}

\author{
Yuksel KAYA*, Musa TURKOZ \\ Bahri Dagdas International Agricultural Research Institute, Konya, TURKEY \\ Corresponding author: yuksel_k@yahoo.com
}

Received: 08.06.2015

\begin{abstract}
If genotype (G) ranks change from one environment (E) to another, genotype by environment interactions (GEI) reflects the need for testing Gs in numerous Es in order to obtain reliable results. The aim of this study was to compare 16 non-parametric stability statistics (NPSSs) for GEI on grain yields of 15 durum wheat genotypes, consisting of 11 advanced lines selected from Turkish National Durum Wheat Breeding Program (TNDWBP) and four checks, tested in 12 rain-fed environments during the 2 cropping seasons (2009-2010 and 2010-2011) in Turkey. The combined ANOVA indicated that G, E and GEI effects were significant for grain yield. According to analyses of NPSSs, the highest in ranking (TOP), percentage of adaptability (PA), rank mean (RM) and yield-stability (YS) statistics were positively associated with grain yield and therefore characterized under the dynamic concept of stability. In addition, spearman rank correlation analysis revealed that only TOP, PA, RM and YS statistics would be useful for simultaneous selection for high grain yield and stability. Based on the 16 NPSSs used in this study, Dumlupinar cultivar (G15) was both the most stable and one of the highest yielding ones. On the other hand, G5 and G7 were the most stable ones among the advanced lines tested, but their yield performances were lower. As a result, this study showed that the crossing block of TNDWBP should be enriched by germplasm being capable of dynamic stability, wide adaptation and higher yielding.
\end{abstract}

Key words: Durum Wheat (T. durum L.), Grain Yield, Genotype by Environment Interaction, Non-parametric Stability Statistics

\section{INTRODUCTION}

Durum wheat landraces were formed around $7000 \mathrm{BC}$ in Anatolia, Turkey (Nesbitt and Samuel, 1996). Turkey is blessed with agro-climatic regions suitable for the cultivation of durum wheat and among the top 3 durum wheat producing countries in the world with $3 \mathrm{Mt}$ of production during 2009 (Yildirim et al., 2013). In Mediterranean Basin, durum wheat is mainly grown under rain-fed conditions, characterized by unpredictable rainfall and a large incidence of abiotic and biotic stresses. Drought and heat during the grain filling period, nutrient deficiencies, soil problems, diseases, and pests are the main yield constraints (Royo et al., 2009). Prevailing abiotic and biotic stresses cause GEIs in MEYTs (Kang, 2002). GEI is one of the overwhelming challenges against adoption and promotion of new cultivars released by durum wheat breeding programs in Mediterranean countries (Habash et al., 2009).

There are two major approaches to studying GEI and determining adaptation of genotypes (Huehn, 1996). The first and most common approach is parametric, which relies on distributional assumptions about genotypic, environmental and GEI effects. The second major approach is the nonparametric or analytical clustering approach, which relates environments and phenotypes relative to biotic and abiotic environmental factors without making specific modeling assumptions. For practical applications, however, most breeding programs incorporate some elements of both approaches (Becker and Leon, 1988).

The parametric stability methods have good properties under certain statistical assumptions, like normal distribution of errors and interaction effects; however, they may not perform well if these assumptions are violated (Huehn, 1990). That means parametric tests for significance of variances and variance-related measures could be very sensitive to the underlying assumptions. Thus, it is wise to search for alternative approaches that are more robust to departures from common assumptions, such as nonparametric measures (Nassar and Huehn, 1987). Thus, the level of association between the estimates of stability and adaptability from different models is the indicative if one or more statistics could be used for reliable prediction of responses in different 
environments. This association can also help breeders to choose statistics that better obey the concept of stability (Duarte and Zimmermann, 1995).

There are several NPSSs commonly used. They can be simply estimated and interpreted. Nonparametric procedures proposed by St Pierre et al. (1967), Langer et al. (1979), Huehn (1979; 1996), Ketata (1988), Fox et al. (1990), Kang and Magari (1995), and Thennarasu (1995) are based on the ranks of genotypes in each environment and genotypes with similar ranking across environments are classified as stable.

The objectives of this study were to (i) identify durum genotypes that have both high mean yield and stable yield performance across different environments for rain-fed areas of Turkey, and (ii) study the relationships among NPSSs.

\section{MATERIALS AND METHODS}

\section{Field Trials}

Fifteen durum wheat genotypes (Table 1) were grown in 12 rain-fed environments (Table 2) from the Central Anatolian Region and Aegean Transitional Zone of Turkey during the two consecutive cropping seasons (2009-2010 and 2010-2011). The genotypes comprised 4 checks (registered cultivars) and 11 advanced lines from
TNDWBP. The experimental layout was a randomized complete block design with 4 replications. Sowing was done with an experimental drill in $1.2 \mathrm{~m}$ by $7 \mathrm{~m}$ plots, consisting of 6 rows spaced $20 \mathrm{~cm}$ apart. The seeding rate was 550 seeds $\mathrm{m}^{-2}$. Fertilizer application was $27 \mathrm{~kg} \mathrm{~N}^{-1}$ and $69 \mathrm{~kg} \mathrm{P}_{2} \mathrm{O}_{5} \mathrm{ha}^{-1}$ at the planting and $50 \mathrm{~kg} \mathrm{~N} \mathrm{ha}^{-1}$ at the stem elongation stage. Harvesting was done with an experimental combine in $1.2 \mathrm{~m}$ by $5 \mathrm{~m}$ plots. Grain yield was obtained by expressing plot grain yields on a hectare basis $\left(\mathrm{t} \mathrm{ha} \mathrm{ha}^{-1}\right)$. Details of the 15 genotypes and 12 environments are given in Tables 1 and 2 , respectively.

\section{Statistical Analyses}

ANOVA, Spearman's rank correlation and comparison of the means with LSD test $(\mathrm{P}<0.05)$ were performed using SASC 9.1. SAS codes proposed by Hussein et al. (2000) for NPSSs $S_{i}{ }^{(3)}$ and $S_{i}{ }^{(6)}$ (Huehn, 1996) and TOP (Fox et al., 1990) and by $\mathrm{Lu}$ (1995) for $\mathrm{S}_{\mathrm{i}}^{(1)}$ and $\mathrm{S}_{\mathrm{i}}^{(2)}$ (Nassar and Huehn, 1987) were used in the analyses. The other NPSSs RM, RSD and YSD (Ketata, 1988), PA (St Pierre et al., 1967), $\mathrm{R}_{1}$ and $\mathrm{R}_{2}$ (Langer et al., 1979), YS (Kang and Magari, 1995), $\mathrm{NP}_{\mathrm{i}}{ }^{(1)}, \mathrm{NP}_{\mathrm{i}}{ }^{(2)}, \mathrm{NP}_{\mathrm{i}}{ }^{(3)}$ and $\mathrm{NP}_{\mathrm{i}}{ }^{(4)}$ (Thennarasu, 1995) were estimated using ExcelC. Principal components analysis (PCA) was performed using Biplot and Singular Value Decomposition Macros for Excel $\mathbb{C}$ (Lipkovich and Smith, 2002).

Table 1. Codes, advanced line parentages and cultivar names of the 15 durum wheat genotypes

\begin{tabular}{|c|c|c|}
\hline Code & Cultivar & $\begin{array}{l}\text { Yield } \\
\left(\mathbf{t} \text { ha }^{-1}\right)\end{array}$ \\
\hline $\mathrm{G} 2$ & KIZLTAN & $3.11 \mathrm{df}$ \\
\hline G6 & KUNDURU & $2.60 \mathrm{~h}$ \\
\hline G11 & ALTINTAS & 3.04 ef \\
\hline \multirow[t]{2}{*}{ G15 } & DUMLUPINAR & $3.28 \mathrm{bd}$ \\
\hline & Advanced line & \\
\hline G1 & KRISTAL//AKBASAK/BOTNO & $3.33 \mathrm{bc}^{\dagger}$ \\
\hline G3 & $\begin{array}{l}\text { BERK/C25-6//RICCYA/KND/3/KND//68111/WARD/5/UV126/61-130//1224-1/3/414- } \\
\text { 44/4/DF21.72//61-130/UVY/3/128-13 }\end{array}$ & $2.94 \mathrm{fg}$ \\
\hline G4 & $\begin{array}{l}\text { BERK/C25-6//RICCYA/KND/3/KND//68111/WARD/5/UV126/61-130//1224-1/3/414- } \\
\text { 44/4/DF21.72//61-130/UVY/3/128-13 }\end{array}$ & $3.43 \mathrm{~b}$ \\
\hline G5 & YERLI//AKBUG"S"/HEVIDIK/3/B52/4/C1252 & $2.98 \mathrm{fg}$ \\
\hline G7 & $\begin{array}{l}\text { ALTINDANE/BERK/7/BR180/4/LAKOTA/3/60-120/LDS//64- } \\
\text { 210/5/BERK/6/PINGIONO"S"/8/DWIRNAZ99-11/9/KUMBET }\end{array}$ & $2.95 \mathrm{fg}$ \\
\hline G8 & BERK/G75T181//BAGACAK"S"/3/KIZILTAN & $3.27 \mathrm{bd}$ \\
\hline G9 & KOBAK2916*61-130/3/GOKALA//BR180/WLS/4/B24SYRIAN-2 & $3.21 \mathrm{ce}$ \\
\hline G10 & HARA456/4/61-130/414-44//68111/WARD/3/69T02/69T11/ZF7113 & $3.83 \mathrm{a}$ \\
\hline G12 & 17-61-130/ÜVY162/64140/WARD & $3.12 \mathrm{df}$ \\
\hline G13 & $\begin{array}{l}\text { ALTINDANE/BERK/7/BR180/4/LAKOTA/3/60-120/LDS//64- } \\
\text { 210/5/BERK/6/PINGIONO"S"/8/DWIRNAZ99-11/9/KUMBET }\end{array}$ & 3.06 ef \\
\hline \multirow[t]{3}{*}{ G14 } & MENCEKI"S"/DWIRNAZ99-6//KUMBET & $2.82 \mathrm{~g}$ \\
\hline & Mean & 3.13 \\
\hline & LSD (0.05) & 0.17 \\
\hline
\end{tabular}


Table 2. Codes, cropping seasons, mean grain yields and precipitation amounts for 12 environments

\begin{tabular}{cllcc}
\hline $\begin{array}{c}\text { Environment } \\
\text { Code }\end{array}$ & $\begin{array}{c}\text { Cropping } \\
\text { Season }\end{array}$ & Location & $\begin{array}{c}\text { Mean } \\
\text { Yield (t ha } \mathbf{~}^{-\mathbf{1}}\end{array}$ & $\begin{array}{c}\text { Precipitation } \\
(\mathbf{m m})\end{array}$ \\
\hline E1 & $2009-2010$ & Konya & $2.80 \mathrm{~g} \dagger$ & 320 \\
E2 & $2009-2010$ & Cumra & $2.60 \mathrm{~h}$ & 281 \\
E3 & $2009-2010$ & Gozlu & $3.21 \mathrm{e}$ & 325 \\
E4 & $2009-2010$ & Kutahya & $1.47 \mathrm{j}$ & 289 \\
E5 & $2009-2010$ & Usak & $1.61 \mathrm{j}$ & 278 \\
E6 & $2010-2011$ & Konya & $2.30 \mathrm{I}$ & 342 \\
E7 & $2010-2011$ & Cumra & $4.56 \mathrm{~b}$ & 311 \\
E8 & $2010-2011$ & Karaman & $3.81 \mathrm{c}$ & 326 \\
E9 & $2010-2011$ & Nigde & $3.85 \mathrm{c}$ & 368 \\
E10 & $2010-2011$ & Aksaray & $4.72 \mathrm{a}$ & 354 \\
E11 & $2010-2011$ & Ankara & $3.61 \mathrm{~d}$ & 398 \\
E12 & $2010-2011$ & Eskisehir & $2.98 \mathrm{f}$ & 345 \\
\hline LSD $(0.05)$ & & 0.157 & \\
\hline
\end{tabular}

†Lower case letters stand for environmental rankings based on LSD (0.05)

\section{RESULTS}

\section{ANOVA and Genotype by Environment Interaction}

The ANOVA revealed that $\mathrm{E}$ and $\mathrm{G}$ main effects and GEI were significant at $\mathrm{P}<0.001$ (Table 3). The Es accounted for the $73.8 \%$ of total variation for grain yield, followed by GEI which captured $20.6 \%$, while G accounted for only $5.6 \%$.

The GEI effect was greater by about four times than the $\mathrm{G}$ effect, indicating the presence of remarkable GEI. It was confirmed by the fact that the GEI mean grain-yield varied from $1.05 \mathrm{t} \mathrm{ha}^{-1}$ for environment E5 to $4.72 \mathrm{t} \mathrm{ha}^{-1}$ for E10 (Table 2).

Genotypic mean grain yields ranged from $2.60 \mathrm{t} \mathrm{ha}^{-1}$ for G6 to $3.82 \mathrm{t} \mathrm{ha}^{-1}$ for G10 with a mean of $3.13 \mathrm{t} \mathrm{ha}^{-1}$ (Table 1). Among the registered cultivars (G2, G6, G11 and G15), merely G15 had higher grain yield than the grand mean, whereas 5 (G10, G4, G1, G8 and G9) out of 11 advanced lines were higher yielding ones.

Table 3. Combined analysis of variance for grain yield data of 15 durum wheat genotypes grown at 12 environments

\begin{tabular}{|c|c|c|c|c|c|c|}
\hline Source & df & SS & MS & $\mathbf{F}$ & Model & Explained (\%) \\
\hline Environment (E) & 11 & 716.11 & 65.10 & $127.58 * * *$ & Random & 73.8 \\
\hline Replication (E) & 36 & 18.37 & 0.51 & & & \\
\hline Genotype (G) & 14 & 54.37 & 3.88 & $2.98 * * *$ & Fix & 5.6 \\
\hline G x E Interaction (GEI) & 154 & 200.50 & 1.30 & $6.74 * * *$ & Random & 20.6 \\
\hline Error & 504 & 97.37 & 0.19 & & & \\
\hline Total & 719 & 1086.72 & & & & 100.0 \\
\hline $\mathrm{CV}_{(\%)}=14.04 \quad \mathrm{R}^{2}=0.91$ & $=3.1$ & & & & & \\
\hline
\end{tabular}

\section{Non-parametric Stability Statistics}

Estimated values and ranks of 16 NPSSs and grain yield means (Y) for 15 durum wheat genotypes tested in 12 environments during the two cropping seasons are presented in Tables 4 and 5, respectively.

Ketata (1988) proposed four NPSSs: rank's mean (RM) and its standard deviation (RSD) and yield mean (Y) and its standard deviation (YSD). According to RM and Y, genotypes G10 and G4 were the most desirable ones, while genotypes G5 and G6 based on YSD and genotypes G7 and G3 based on RSD were identified as the most stable ones (Tables 4 and 5). However G3, G5, G6 and $\mathrm{G} 7$ were lower yielding genotypes.

The NPSS of Fox et al. (1990) consists of scoring the percentage of environments in which each genotype ranked in the TOP, MIDDLE and BOTTOM third of trial entries. A genotype usually found in the TOP third of entries across environments can be considered relatively well adapted and stable. Thus, G4 and G10 were adapted genotypes, because they ranked in the TOP third of genotypes in a high percentage of environments (high TOP value, $67 \%$ ), and was followed by G15 (50\%) (Tables 4 and 5). The undesirable genotypes identified by this method were G3, G6 and G7.

Kang and Magari (1995) proposed a NPSS, YS, uses both yield (Y) and Shukla's stability (S) variance (Shukla, 1972). The genotypes with the highest YS values are the most favorable ones. According to the YS statistic, G1 and G15 had the highest values and therefore were stable genotypes with high yield, followed by G9 and G10 (Tables 4 and 5). 
Table 4. Mean grain yield (Y) and estimates of 16 non-parametric stability statistics for 15 durum wheat genotypes tested in 12 environments

\begin{tabular}{|c|c|c|c|c|c|c|c|c|c|}
\hline Genotype & $\mathrm{Y}^{\dagger}$ & YSD & RM & RSD & TOP & YS & PA & $\mathrm{R}_{1}$ & $\mathrm{R}_{2}$ \\
\hline G1 & 3.33 & 1.29 & 6.75 & 4.03 & 41.66 & 15 & 50.00 & 4.04 & 4.04 \\
\hline $\mathrm{G} 2$ & 3.11 & 1.33 & 8.58 & 5.58 & 41.66 & 7 & 50.00 & 4.18 & 2.69 \\
\hline G3 & 2.94 & 1.05 & 8.92 & 3.09 & 8.33 & 1 & 33.33 & 3.58 & 3.58 \\
\hline G4 & 3.43 & 1.38 & 5.33 & 4.62 & 66.66 & 9 & 75.00 & 3.87 & 3.87 \\
\hline G5 & 2.98 & 0.96 & 8.75 & 3.36 & 25.00 & 4 & 33.33 & 2.75 & 2.55 \\
\hline G6 & 2.60 & 0.79 & 12.08 & 3.34 & 8.33 & -3 & 16.67 & 2.33 & 1.90 \\
\hline G7 & 2.95 & 1.02 & 10.00 & 1.65 & 0.00 & -6 & 8.33 & 3.31 & 3.31 \\
\hline G8 & 3.27 & 1.47 & 7.58 & 5.00 & 41.66 & 4 & 50.00 & 4.40 & 3.62 \\
\hline G9 & 3.21 & 1.17 & 8.25 & 4.47 & 41.66 & 11 & 41.67 & 4.08 & 4.08 \\
\hline G10 & 3.83 & 1.61 & 4.25 & 4.56 & 66.66 & 11 & 75.00 & 5.76 & 5.76 \\
\hline G11 & 3.04 & 1.01 & 9.08 & 4.27 & 25.00 & 5 & 41.67 & 2.83 & 2.63 \\
\hline G12 & 3.12 & 1.07 & 8.42 & 4.10 & 16.66 & 8 & 41.67 & 3.16 & 2.84 \\
\hline G13 & 3.06 & 0.97 & 7.58 & 3.96 & 33.33 & 6 & 50.00 & 3.00 & 2.84 \\
\hline G14 & 2.82 & 1.11 & 8.08 & 4.56 & 33.33 & -8 & 66.67 & 3.61 & 1.26 \\
\hline G15 & 3.28 & 1.19 & 6.33 & 3.23 & 50.00 & 13 & 75.00 & 3.77 & 3.77 \\
\hline Mean & 3.13 & 1.16 & 8.00 & 3.99 & 33.33 & 5.13 & 47.22 & 3.64 & 3.25 \\
\hline Genotype & $\mathrm{S}_{\mathrm{i}}^{(1)}$ & $\mathrm{S}_{\mathrm{i}}^{(2)}$ & $\mathrm{S}_{\mathrm{i}}^{(3)}$ & $\mathrm{S}_{\mathrm{i}}^{(6)}$ & $\mathrm{NP}_{\mathrm{i}}^{(1)}$ & $\mathrm{NP}_{\mathrm{i}}^{(2)}$ & $\mathrm{NP}_{\mathrm{i}}^{(3)}$ & $\mathrm{NP}_{\mathrm{i}}^{(4)}$ & \\
\hline G1 & 5.68 & 25.53 & 26.36 & 5.75 & 4.08 & 0.58 & 0.72 & 0.63 & \\
\hline $\mathrm{G} 2$ & $6.57 *$ & $30.87^{*}$ & 38.90 & 7.01 & 4.83 & 0.51 & 0.62 & 0.80 & \\
\hline G3 & 4.27 & 13.36 & 11.07 & 3.40 & 2.83 & 0.31 & 0.39 & 0.57 & \\
\hline G4 & 5.81 & 24.69 & 46.31 & 8.51 & 4.50 & 1.13 & 0.89 & 0.74 & \\
\hline G5 & 3.93 & 10.96 & 14.20 & 3.88 & 2.67 & 0.27 & 0.36 & 0.51 & \\
\hline G6 & 6.00 & 25.60 & 10.04 & 2.45 & 4.33 & 0.32 & 0.40 & 0.84 & \\
\hline G7 & $2.07 * *$ & $3.29 * *$ & 3.00 & 1.40 & 1.42 & 0.14 & 0.17 & 0.27 & \\
\hline G8 & 5.87 & 25.15 & 36.27 & 6.49 & 4.33 & 0.58 & 0.63 & 0.70 & \\
\hline G9 & 5.96 & 25.54 & 26.69 & 5.45 & 4.33 & 0.51 & 0.59 & 0.70 & \\
\hline G10 & 6.18 & $29.06^{*}$ & 51.23 & 10.47 & 4.50 & 4.50 & 1.21 & 0.63 & \\
\hline G11 & 4.26 & 13.05 & 22.50 & 4.93 & 3.08 & 0.29 & 0.39 & 0.50 & \\
\hline G12 & 4.89 & 17.35 & 21.44 & 4.20 & 3.42 & 0.43 & 0.47 & 0.58 & \\
\hline G13 & 4.68 & 15.70 & 23.48 & 5.18 & 3.17 & 0.40 & 0.49 & 0.62 & \\
\hline G14 & 5.25 & 24.62 & 28.62 & 5.67 & 3.42 & 0.49 & 0.59 & 0.97 & \\
\hline G15 & $2.74 * *$ & $5.65 *$ & 17.67 & 4.46 & 1.75 & 0.32 & 0.36 & 0.33 & \\
\hline Mean & 4.94 & 19.36 & 25.19 & 5.28 & 3.51 & 0.72 & 0.55 & 0.63 & \\
\hline
\end{tabular}

$* \mathrm{P}<0.05$, **P<0.01 ${ }^{\dagger}$ Symbols: Y-Mean yield $\left(\mathrm{t} \mathrm{ha}^{-1}\right)$, YSD-Yield standard deviation, RM-Rank mean, RSD-Rrank's standard deviation (Ketata, 1988), YS-Yield stability statistic (Kang and Magari, 1995), PA-Percentage of adaptability (St-Pierre et al., 1967), $R_{1}$ and $R_{2}-R_{\text {Range indexes (Langer }}$ et al., 1979), TOP-Proportion of environments in which a genotype ranked in the top third (Fox et al., 1990), $S_{i}^{(1)}, S_{i}{ }^{(2)}, S_{i}^{(3)}$ and $S_{i}^{(6)}-R_{a n k s}$ of adjusted yield means of genotypes (Huehn, 1979), $\mathrm{NP}_{\mathrm{i}}^{(1)}, \mathrm{NP}_{\mathrm{i}}^{(2)} \mathrm{NP}_{\mathrm{i}}^{(3)}$ and $\mathrm{NP}_{\mathrm{i}}^{(4)}$-Ranks of adjusted yield means of genotypes (Thennarasu, 1995).

A genotype can be evaluated for its adaptation using the percentage of adaptability (PA) (St Pierre et al., 1967). This method measures proportion of environments in which is a given genotype outperforms the average of all genotypes including in the trial (Duarte, Zimmermann, 1995). The genotypes G4, G10 and G15 had the highest PA value $(75 \%)$, which indicates that the yields of these genotypes were superior to the overall yield of the 15 genotypes in the trials, while $\mathrm{G} 7$ had lowest PA value $(8.33 \%)$ (Tables 4 and 5$)$.

Langer et al. (1979) suggested two indexes $\left(\mathrm{R}_{1}\right.$ and $\left.\mathrm{R}_{2}\right)$ related to the ranges in productivity of genotypes as crude measures of production response. The first, denoted $\mathrm{R}_{1}$, equals the difference between the minimum and maximum yields of a genotype in a series of environments, and the second, denoted $\mathrm{R}_{2}$, is the difference between the yields of a variety in the lowest and best production environments. Based on statistic $R_{1}$, the most stable genotypes were G6,
G5 and G11 with lower yields, whereas G10, G8 and G2 were unstable ones with higher yields (Tables 4 and 5). As for $\mathrm{R}_{2}, \mathrm{G14}$, G6 and G5 were the most stable and lower yielding genotypes. However, the unstable were G10, G9 and G1 whose yields were higher than the average.

NPSSs $\mathrm{S}_{\mathrm{i}}^{(1)}, \mathrm{S}_{\mathrm{i}}{ }^{(2)}, \mathrm{S}_{\mathrm{i}}{ }^{(3)}$ and $\mathrm{S}_{\mathrm{i}}{ }^{(6)}$ were developed by Huehn (1979; 1996). The $S_{i}{ }^{(1)}$ and $S_{i}{ }^{(2)}$ statistics are based on ranks of genotypes across environments and they give equal weight to each environment. Genotypes with fewer changes in rank are considered to be more stable (Becker and Leon, 1988). These two statistics ranked genotypes similarity for stability. The significance tests for $\mathrm{S}_{\mathrm{i}}{ }^{(1)}$ and $\mathrm{S}_{\mathrm{i}}{ }^{(2)}$ were also developed by Nassar and Huehn (1987). According to significance levels of $\mathrm{X}^{2}$ tests for $\mathrm{S}_{\mathrm{i}}{ }^{(1)}$ and $\mathrm{S}_{\mathrm{i}}{ }^{(2)}$, there were significant differences in rank stability among the 15 genotypes grown in 12 environments. Genotypes $\mathrm{G} 15$ and $\mathrm{G} 7$ had the lowest values of $\mathrm{S}_{\mathrm{i}}{ }^{(1)}$ $(\mathrm{P}<0.01)$ while $\mathrm{G} 2$ had the highest in $\mathrm{S}_{\mathrm{i}}{ }^{(1)}(\mathrm{P}<0.05)$. In 
case of $\mathrm{S}_{\mathrm{i}}{ }^{(2)}, \mathrm{G} 7$ and $\mathrm{G} 15$ also the lowest values $(\mathrm{P}<0.01$ and 0.05 , respectively), whereas $\mathrm{G} 2$ and G10 had highest values of $\mathrm{S}_{\mathrm{i}}^{(2)}(\mathrm{p}<0.05)$. If $\mathrm{S}_{\mathrm{i}}^{(1)}$ and $\mathrm{S}_{\mathrm{i}}^{(2)}=0$, it refers a stable genotype (Huehn, 1990). For both statistics, G7 and G15 were stable, but the former was lower yielding and the latter was higher yielding (Tables 4 and 5).

The statistics $\mathrm{S}_{\mathrm{i}}{ }^{(3)}$ and $\mathrm{S}_{\mathrm{i}}{ }^{(6)}$ combine yield and stability based on yield ranks of genotypes in each environment.
These parameters measure stability in units of the mean rank of each genotype (Huehn, 1979). The lowest value for each of these statistics indicates maximum stability for a certain genotype. As for $\mathrm{S}_{\mathrm{i}}{ }^{(1)}$ and $\mathrm{S}_{\mathrm{i}}{ }^{(2)}, \mathrm{G} 7$ was the most stable according to the $\mathrm{S}_{\mathrm{i}}{ }^{(3)}$ and $\mathrm{S}_{\mathrm{i}}{ }^{(6)}$ parameters. The mean yield of G7 followed by G6 and G3 were the lowest genotypes tested. The highest mean yield was for G10 followed G4, but they were unstable (Tables 4 and 5).

Table 5. Rank order of 15 durum wheat genotypes based on 16 non-parametric stability statistics

\begin{tabular}{|c|c|c|c|c|c|c|c|c|c|}
\hline Genotype & $\mathrm{Y}^{\dagger}$ & YSD & RM & RSD & TOP & YS & PA & $\mathrm{R}_{1}$ & $\mathrm{R}_{2}$ \\
\hline G1 & 3 & 11 & 4 & 7 & 3 & 1 & 3 & 11 & 13 \\
\hline G2 & 8 & 12 & 9 & 14 & 3 & 6 & 3 & 13 & 5 \\
\hline G3 & 13 & 6 & 11 & 2 & 7 & 10 & 5 & 7 & 9 \\
\hline G4 & 2 & 13 & 2 & 12 & 1 & 4 & 1 & 10 & 12 \\
\hline G5 & 11 & 2 & 10 & 5 & 5 & 9 & 5 & 2 & 3 \\
\hline G6 & 15 & 1 & 14 & 4 & 7 & 11 & 6 & 1 & 2 \\
\hline G7 & 12 & 5 & 13 & 1 & 8 & 12 & 7 & 6 & 8 \\
\hline G8 & 5 & 14 & 5 & 13 & 3 & 9 & 3 & 14 & 10 \\
\hline G9 & 6 & 9 & 7 & 10 & 3 & 3 & 4 & 12 & 14 \\
\hline G10 & 1 & 15 & 1 & 11 & 1 & 3 & 1 & 15 & 15 \\
\hline G11 & 10 & 4 & 12 & 9 & 5 & 8 & 4 & 3 & 4 \\
\hline G12 & 7 & 7 & 8 & 8 & 6 & 5 & 4 & 5 & 6 \\
\hline G13 & 9 & 3 & 5 & 6 & 4 & 7 & 3 & 4 & 7 \\
\hline G14 & 14 & 8 & 6 & 11 & 4 & 13 & 2 & 8 & 1 \\
\hline G15 & 4 & 10 & 3 & 3 & 2 & 2 & 1 & 9 & 11 \\
\hline Mean & 8.00 & 8.00 & 7.33 & 7.73 & 4.13 & 6.87 & 3.47 & 8.00 & 8.00 \\
\hline Genotype & $\mathrm{S}_{\mathrm{i}}^{(1)}$ & $\mathrm{S}_{\mathrm{i}}^{(2)}$ & $\mathrm{S}_{\mathrm{i}}^{(3)}$ & $\mathrm{S}_{\mathrm{i}}^{(6)}$ & $\mathrm{NP}_{\mathrm{i}}^{(1)}$ & $\mathrm{NP}_{\mathrm{i}}^{(2)}$ & $\mathrm{NP}_{\mathrm{i}}^{(3)}$ & $\mathrm{NP}_{\mathrm{i}}^{(4)}$ & \\
\hline G1 & 9 & 11 & 9 & 11 & 8 & 10 & 10 & 8 & \\
\hline $\mathrm{G} 2$ & 15 & 15 & 13 & 13 & 11 & 9 & 8 & 11 & \\
\hline G3 & 5 & 5 & 3 & 3 & 4 & 4 & 3 & 5 & \\
\hline G4 & 10 & 9 & 14 & 14 & 10 & 11 & 11 & 10 & \\
\hline G5 & 3 & 3 & 4 & 4 & 3 & 2 & 2 & 4 & \\
\hline G6 & 13 & 13 & 2 & 2 & 9 & 5 & 4 & 12 & \\
\hline G7 & 1 & 1 & 1 & 1 & 1 & 1 & 1 & 1 & \\
\hline G8 & 11 & 10 & 12 & 12 & 9 & 10 & 9 & 9 & \\
\hline G9 & 12 & 12 & 10 & 9 & 9 & 9 & 7 & 9 & \\
\hline G10 & 14 & 14 & 15 & 15 & 10 & 12 & 12 & 8 & \\
\hline G11 & 4 & 4 & 7 & 7 & 5 & 3 & 3 & 3 & \\
\hline G12 & 7 & 7 & 6 & 5 & 7 & 7 & 5 & 6 & \\
\hline G13 & 6 & 6 & 8 & 8 & 6 & 6 & 6 & 7 & \\
\hline G14 & 8 & 8 & 11 & 10 & 7 & 8 & 7 & 13 & \\
\hline G15 & 2 & 2 & 5 & 6 & 2 & 5 & 2 & 2 & \\
\hline Mean & 8.00 & 8.00 & 8.00 & 8.00 & 6.73 & 6.80 & 6.00 & 7.20 & \\
\hline
\end{tabular}

${ }^{\dagger}$ Symbols: Y-Mean yield $\left(\mathrm{t} \mathrm{ha}^{-1}\right)$, YSD-Yield standard deviation, RM-Rank mean, RSD-Rrank's standard deviation (Ketata, 1988), YS-Yield stability statistic (Kang and Magari, 1995), PA-Percentage of adaptability (St-Pierre et al., 1967), $\mathrm{R}_{1}$ and $\mathrm{R}_{2}$-Range indexes (Langer et al., 1979), TOPProportion of environments in which a genotype ranked in the top third (Fox et al., 1990), $\mathrm{S}_{\mathrm{i}}^{(1)}, \mathrm{S}_{\mathrm{i}}^{(2)}, \mathrm{S}_{\mathrm{i}}^{(3)}$ and $\mathrm{S}_{\mathrm{i}}^{(6)}$-Ranks of adjusted yield means of genotypes (Huehn, 1979), $\mathrm{NP}_{\mathrm{i}}^{(1)}, \mathrm{NP}_{\mathrm{i}}^{(2)} \mathrm{NP}_{\mathrm{i}}^{\left({ }^{(3)}\right.}$ and $\mathrm{NP}_{\mathrm{i}}^{(4)}$-Ranks of adjusted yield means of genotypes (Thennarasu, 1995).

Results of Thennarasu's (1995) NPSSs, which are calculated from ranks of adjusted yield means and the ranks of genotypes considering these NPSSs, are shown in Tables 4 and 5. According to the first method $\left(\mathrm{NP}_{\mathrm{i}}^{(1)}\right)$, genotypes G7, G15 and G5 were stable in comparison with the other genotypes. Genotype G7 had the lowest value of $\mathrm{NP}_{\mathrm{i}}^{(2)}$ and was stable, followed by G5 and G11. Because of the high values for $\mathrm{NP}_{\mathrm{i}}{ }^{(2)}$, the stabilities of $\mathrm{G} 10$ followed by G4 were low, although they had the highest mean yield (Table 4). $\mathrm{NP}_{\mathrm{i}}^{(3)}$, like $\mathrm{NP}_{\mathrm{i}}^{(2)}$, identified $\mathrm{G} 7$ as the most stable genotype, although it was one of the lowest yielding genotypes. The next most stable genotypes were G5 and G15 which the former had low mean yield performance but the latter did not. The unstable genotypes based on $\mathrm{NP}_{\mathrm{i}}{ }^{(3)}$ were $\mathrm{G} 10$ followed by G4 and G1, which had the highest mean yields. Stability parameter $\mathrm{NP}_{\mathrm{i}}^{(4)}$ identified $\mathrm{G} 7$ as a stable genotype, followed by $\mathrm{G} 15$ and $\mathrm{G} 11$; but like $\mathrm{NP}_{\mathrm{i}}^{(2)}$ and $\mathrm{NP}_{\mathrm{i}}{ }^{(3)}$, identified G14, G6 and G2 as unstable. The results of three NPs $\left(\mathrm{NP}_{\mathrm{i}}^{(1)}, \mathrm{NP}_{\mathrm{i}}^{(2)}\right.$ and $\left.\mathrm{NP}_{\mathrm{i}}^{(3)}\right)$ were very similar to 
each other and identified G10 and G4 as unstable, although they had the highest mean yield performances. According to all of Thennarasu's (1995) NPSSs, G7 was the most stable genotype, although it was one of the lowest mean yielding ones.

\section{Relationships among the Non-parametric Stability Statistics}

The Spearman's rank correlations between each pair of NPSSs (Table 6) demonstrated positive significant rank correlations between mean yield $(\mathrm{Y}), \mathrm{RM}\left(\mathrm{r}=0.83^{* *}\right)$,
TOP $\left(\mathrm{r}=0.83^{* *}\right)$, YS $(\mathrm{r}=0.87)$ and PA $\left(\mathrm{r}=0.71^{* *}\right)$, but negative significant with $\mathrm{YSD}\left(\mathrm{r}=-0.80^{* *}\right), \mathrm{R}_{1}(\mathrm{r}=-$ $0.70 * *), \mathrm{R}_{2}(\mathrm{r}=-0.82 * *), \mathrm{S}_{\mathrm{i}}{ }^{(3)}\left(\mathrm{r}=-0.65^{* *}\right), \mathrm{S}_{\mathrm{i}}{ }^{(6)}(\mathrm{r}=-$ $\left.0.71^{* *}\right), \mathrm{NP}_{\mathrm{i}}^{(2)}\left(\mathrm{r}=-0.70^{* *}\right)$ and $\mathrm{NP}_{\mathrm{i}}^{(3)}(\mathrm{r}=-0.67)$. Mean yield showed negative but non-significant correlation coefficients with $\mathrm{RSD}, \mathrm{S}_{\mathrm{i}}^{(1)}, \mathrm{S}_{\mathrm{i}}{ }^{(2)}$ and $\mathrm{NP}_{\mathrm{i}}^{(1)}$, while it exhibited independence in relation to $\mathrm{NP}_{\mathrm{i}}{ }^{(4)}$. Standard deviation of mean yield (YSD) was significantly positively associated with $\mathrm{RSD}, \mathrm{R}_{1}, \mathrm{R}_{2}, \mathrm{~S}_{\mathrm{i}}{ }^{(1)}, \mathrm{S}_{\mathrm{i}}{ }^{(3)}, \mathrm{S}_{\mathrm{i}}{ }^{(6)}$, $\mathrm{NP}_{\mathrm{i}}^{(1)}, \mathrm{NP}_{\mathrm{i}}^{(2)}$ and $\mathrm{NP}_{\mathrm{i}}^{(3)}$, while had negative significant relations with RM, TOP, YS and PA.

Table 6. Spearman's rank correlation coefficients between yield means (Y) and 16 non-parametric stability statistics of 15 durum wheat genotypes tested in 12 environments

\begin{tabular}{|c|c|c|c|c|c|c|c|c|c|}
\hline & $\overline{\mathrm{Y}^{\dagger}}$ & YSD & $\overline{\mathrm{RM}}$ & $\overline{R S D}$ & TOP & $\overline{Y S}$ & $\overline{\mathrm{PA}}$ & $\overline{\mathrm{R}_{1}}$ & $\mathrm{R}_{2}$ \\
\hline $\mathrm{Y}$ & 1.00 & & & & & & & & \\
\hline YSD & $-0.80 * *$ & 1.00 & & & & & & & \\
\hline $\mathrm{RM}$ & $0.83^{* *}$ & $-0.75 * *$ & 1.00 & & & & & & \\
\hline RSD & -0.45 & $0.65 * *$ & -0.46 & 1.00 & & & & & \\
\hline TOP & $0.83 * *$ & $-0.77 * *$ & $0.89 * *$ & $-0.66 * *$ & 1.00 & & & & \\
\hline YS & $0.87^{* *}$ & $-0.55^{*}$ & $0.67 * *$ & -0.24 & $0.70 * *$ & 1.00 & & & \\
\hline PA & $0.71 * *$ & $-0.72 * *$ & $0.91 * *$ & $-0.58^{*}$ & $0.91 * *$ & $0.58 *$ & 1.00 & & \\
\hline $\mathrm{R}_{1}$ & $-0.70 * *$ & $0.95 * *$ & $-0.67 * *$ & $0.61 *$ & $-0.71 * *$ & $-0.50 *$ & $-0.59 *$ & 1.00 & \\
\hline $\mathrm{R}_{2}$ & $-0.82 * *$ & $0.68 * *$ & $-0.65 * *$ & 0.12 & $-0.57 *$ & $-0.74 * *$ & -0.42 & $0.70 * *$ & 1.00 \\
\hline $\mathrm{Si}^{(1)}$ & -0.30 & $0.51 *$ & -0.27 & $0.70 * *$ & -0.44 & -0.25 & -0.30 & $0.55 *$ & 0.21 \\
\hline $\mathrm{Si}^{(2)}$ & -0.30 & 0.49 & -0.26 & $0.66^{* *}$ & -0.43 & -0.29 & -0.28 & $0.55^{*}$ & 0.22 \\
\hline $\mathrm{Si}^{(3)}$ & $-0.65 * *$ & $0.80 * *$ & $-0.73 * *$ & $0.91 * *$ & $-0.85^{* *}$ & -0.43 & $-0.78 * *$ & $0.76^{* *}$ & 0.40 \\
\hline $\mathrm{Si}^{(6)}$ & $-0.71 * *$ & $0.83 * *$ & $-0.77 * *$ & $0.87 * *$ & $-0.88 * *$ & $-0.50 *$ & $-0.80 * *$ & $0.79 * *$ & 0.46 \\
\hline $\mathrm{NPi}^{(1)}$ & -0.39 & $0.54 *$ & -0.36 & $0.81 * *$ & $-0.52 *$ & -0.31 & -0.41 & $0.53 *$ & 0.21 \\
\hline $\mathrm{NPi}^{(2)}$ & $-0.70 * *$ & $0.83 * *$ & $-0.76 * *$ & $0.77 * *$ & $-0.78 * *$ & $-0.55^{*}$ & $-0.71 * *$ & $0.79 * *$ & $0.54 *$ \\
\hline $\mathrm{NPi}^{(3)}$ & $-0.67 * *$ & $0.77 * *$ & $-0.72 * *$ & $0.77 * *$ & $-0.74 * *$ & -0.47 & $-0.65 * *$ & $0.73 * *$ & $0.51 *$ \\
\hline $\mathrm{NPi}^{(4)}$ & 0.05 & 0.29 & -0.22 & $0.64 * *$ & -0.32 & 0.05 & -0.30 & 0.31 & -0.12 \\
\hline & $\mathrm{Si}^{(1)}$ & $\mathrm{Si}^{(2)}$ & $\mathrm{Si}^{(3)}$ & $\mathrm{Si}^{(6)}$ & $\mathrm{NPi}^{(1)}$ & $\mathrm{NPi}^{(2)}$ & $\mathrm{NPi}^{(3)}$ & $\mathrm{NPi}^{(4)}$ & $\mathrm{Si}^{(1)}$ \\
\hline $\mathrm{Si}^{(1)}$ & 1.00 & & & & & & & & \\
\hline $\mathrm{Si}^{(2)}$ & $0.99 * *$ & 1.00 & & & & & & & \\
\hline $\mathrm{Si}^{(3)}$ & $0.67 * *$ & $0.64 * *$ & 1.00 & & & & & & \\
\hline $\mathrm{Si}^{(6)}$ & $0.65^{* *}$ & $0.63^{* *}$ & $0.99 * *$ & 1.00 & & & & & \\
\hline $\mathrm{NPi}^{(1)}$ & $0.96 * *$ & $0.94 * *$ & $0.77 * *$ & $0.74 * *$ & 1.00 & & & & \\
\hline $\mathrm{NPi}^{(2)}$ & $0.79 * *$ & $0.78 * *$ & $0.89 * *$ & $0.90 * *$ & $0.85^{* *}$ & 1.00 & & & \\
\hline $\mathrm{NPi}^{(3)}$ & $0.77 * *$ & $0.77 * *$ & $0.90 * *$ & $0.92 * *$ & $0.85^{* *}$ & $0.96^{* *}$ & 1.00 & & \\
\hline $\mathrm{NPi}^{(4)}$ & $0.83^{* *}$ & $0.82 * *$ & $0.57^{*}$ & $0.53^{*}$ & $0.84 * *$ & $0.68 * *$ & $0.66^{* *}$ & 1.00 & \\
\hline
\end{tabular}

$* \mathrm{P}<0.05, * * \mathrm{P}<0.01{ }^{\dagger}$ Symbols: Y-Mean yield $\left(\mathrm{t} \mathrm{ha}^{-1}\right)$, YSD-Yield standard deviation, RM-Rank mean, RSD-Rrank's standard deviation (Ketata, 1988), YS-Yield stability statistic (Kang and Magari, 1995), PA-Percentage of adaptability (St-Pierre et al., 1967), $R_{1}$ and $R_{2}$-Range indexes (Langer et al., 1979), TOP-Proportion of environments in which a genotype ranked in the top third (Fox et al., 1990), $\mathrm{S}_{\mathrm{i}}^{(1)}, \mathrm{S}_{\mathrm{i}}{ }^{(2)}, \mathrm{S}_{\mathrm{i}}^{(3)}$ and $\mathrm{S}_{\mathrm{i}}^{(6)}-\mathrm{Ranks}$ of adjusted yield means of genotypes (Huehn, 1979), $\mathrm{NP}_{\mathrm{i}}^{(1)}, \mathrm{NP}_{\mathrm{i}}^{(2)} \mathrm{NP}_{\mathrm{i}}^{(3)}$ and $\mathrm{NP}_{\mathrm{i}}^{(4)}$-Ranks of adjusted yield means of genotypes (Thennarasu, 1995).

Rank's mean (RM) was significantly positively correlated with TOP, YS and PA. Conversely, it possessed significantly negatively relations to $\mathrm{R}_{1}, \mathrm{R}_{2}, \mathrm{~S}_{\mathrm{i}}{ }^{(3)}, \mathrm{S}_{\mathrm{i}}{ }^{(6)}$, $\mathrm{NP}_{\mathrm{i}}^{(2)}$ and $\mathrm{NP}_{\mathrm{i}}^{(3)}$. As for standard deviation of rank (RSD), it showed negative significant correlations with TOP and PA. On the other hand, RSD had positive significant associations with $\mathrm{R}_{1}, \mathrm{~S}_{\mathrm{i}}^{(1)}, \mathrm{S}_{\mathrm{i}}^{\left({ }^{(3)}\right.}, \mathrm{S}_{\mathrm{i}}{ }^{(6)}, \mathrm{NP}_{\mathrm{i}}^{(1)}, \mathrm{NP}_{\mathrm{i}}^{(2)}, \mathrm{NP}_{\mathrm{i}}^{(3)}$ and $\mathrm{NP}_{\mathrm{i}}^{(4)}$.

The percentage of environments in which it ranked in the top third of genotypes (TOP) exhibited positive significant relationships with YS and PA. In contrast, it was negative significant relations with $\mathrm{R}_{1}, \mathrm{R}_{2}, \mathrm{~S}_{\mathrm{i}}{ }^{(3)}, \mathrm{S}_{\mathrm{i}}{ }^{(6)}$, $\mathrm{NP}_{\mathrm{i}}^{(1)}, \mathrm{NP}_{\mathrm{i}}^{(2)}$ and $\mathrm{NP}_{\mathrm{i}}^{(3)}$.

Yield-stability statistic (YS) had negative significant correlations with $\mathrm{R}_{1}, \mathrm{R}_{2}, \mathrm{~S}_{\mathrm{i}}{ }^{(6)}$ and $\mathrm{NP}_{\mathrm{i}}{ }^{(2)}$, but merely a positive significant relation with $\mathrm{PA}$. In case of the percentage of adaptability (PA), it had negative significant correlations with $\mathrm{R}_{1}, \mathrm{~S}_{\mathrm{i}}{ }^{(3)}, \mathrm{S}_{\mathrm{i}}^{\left({ }^{(6)}\right.}, \mathrm{NP}_{\mathrm{i}}{ }^{(2)}$ and $\mathrm{NP}_{\mathrm{i}}{ }^{(3)}$.

From the genotype yield mean ranges or indices in differential responses to test environments, the first range or index, $\mathrm{R}_{1}$, exhibited positive significant associations with $\mathrm{R}_{2}, \mathrm{~S}_{\mathrm{i}}^{(1)}, \mathrm{S}_{\mathrm{i}}^{(2)}, \mathrm{S}_{\mathrm{i}}^{(3)}, \mathrm{S}_{\mathrm{i}}^{(6)}, \mathrm{NP}_{\mathrm{i}}^{(1)}, \mathrm{NP}_{\mathrm{i}}^{(2)}$ and $\mathrm{NP}_{\mathrm{i}}^{(3)}$. 
Meanwhile, the second range, $\mathrm{R}_{2}$, was significantly positively correlated with $\mathrm{NP}_{\mathrm{i}}{ }^{(2)}$ and $\mathrm{NP}_{\mathrm{i}}{ }^{(3)}$.

The all pair-wise correlation coefficients among the NPSSs $\mathrm{S}_{\mathrm{i}}{ }^{(1)}, \mathrm{S}_{\mathrm{i}}{ }^{(2)}, \mathrm{S}_{\mathrm{i}}{ }^{(3)}, \mathrm{S}_{\mathrm{i}}{ }^{(6)}, \mathrm{NP}_{\mathrm{i}}{ }^{(1)}, \mathrm{NP}_{\mathrm{i}}{ }^{(2)}, \mathrm{NP}_{\mathrm{i}}^{\left({ }^{(3)}\right.}$ and $\mathrm{NP}_{\mathrm{i}}^{(4)}$ were positively significant at $\mathrm{P}<0.01$.

\section{Principal Components Analysis}

To better understand the relationships among the NPSSs, a principal components analysis (PCA) based on the rank (Table 5) correlation matrix (Table 6) was performed. According to the PCA, the two first principal components (PCs) explained $84 \%$ (66 and $18 \%$ by PC1 and $\mathrm{PC} 2$, respectively) of the total variance of the original variables. The relationships among the 16 NPSSs with yield mean are graphically displayed in a biplot, depicted by PC1 vs. PC2 scores (Figure 1). In this biplot, the first PC1 axis visually distinguished the all NPSSs into three groups. Group 1 consisted of Y, TOP, YS, RM and PA, where were grouped at the negative side of $\mathrm{PC} 1$ axis. Group 2 comprised $\mathrm{NP}_{\mathrm{i}}^{(4)}, \mathrm{S}_{\mathrm{i}}^{(2)}, \mathrm{S}_{\mathrm{i}}^{(1)}, \mathrm{NP}_{\mathrm{i}}{ }^{(1)}$ and RSD while Group 3 had $\mathrm{NP}_{\mathrm{i}}{ }^{(3)}, \mathrm{NP}_{\mathrm{i}}^{(2)}, \mathrm{S}_{\mathrm{i}}^{\left({ }^{(3)}\right.}, \mathrm{S}_{\mathrm{i}}{ }^{(6)}, \mathrm{R}_{1}, \mathrm{YSD}$ and $\mathrm{R}_{2}$, where both were located at the positive side of PC1 axis. NPSSs from Group 2 were insignificantly but negatively correlated with the NPSSs from Group 1. In contrast, NPSSs from Group 3 were significantly negatively correlated with the NPSSs from Group 1 (Table 6).

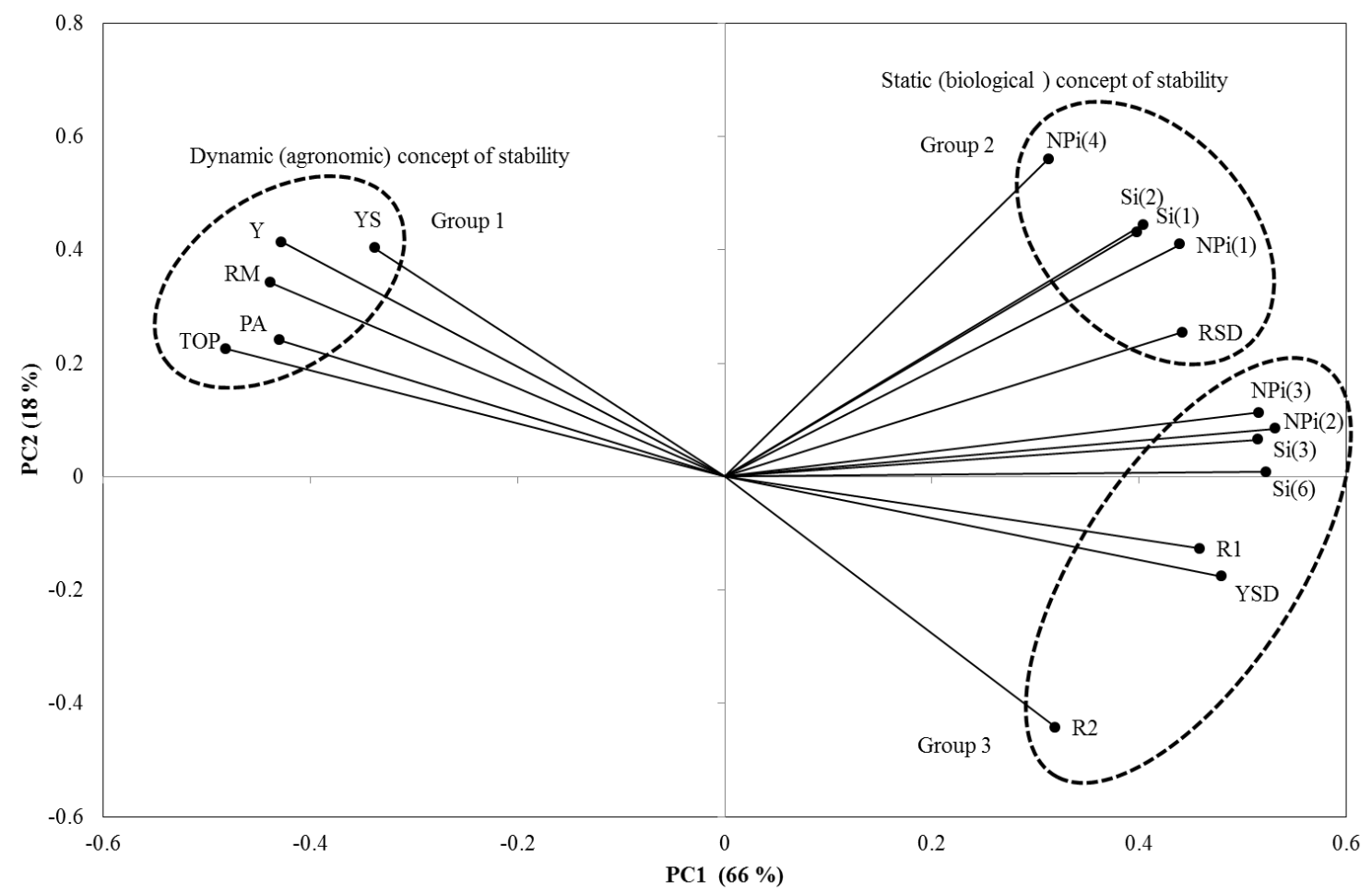

Figure 1. Biplot, which was depicted by PC1 vs. PC2 scores, obtained from principal component analysis conducted based on ranks of 15 durum wheat genotypes for 16 non-parametric stability statistics.

Symbols: Y-Mean yield ( $\mathrm{t} \mathrm{ha}^{-1}$ ), YSD-Yield standard deviation, RM-Rank mean, RSD-Rrank's standard deviation (Ketata, 1988), YS-Yield stability statistic (Kang and Magari, 1995), PA-Percentage of adaptability (St-Pierre et al., 1967), $\mathrm{R}_{1}$ and $\mathrm{R}_{2}$-Range indexes (Langer et al., 1979), TOPProportion of environments in which a genotype ranked in the top third (Fox et al., 1990), $\mathrm{S}_{\mathrm{i}}^{(1)}, \mathrm{S}_{\mathrm{i}}^{(2)}, \mathrm{S}_{\mathrm{i}}{ }^{(3)}$ and $\mathrm{S}_{\mathrm{i}}^{(6)}$-Ranks of adjusted yield means of genotypes (Huehn, 1979), $\mathrm{NP}_{\mathrm{i}}^{(1)}, \mathrm{NP}_{\mathrm{i}}^{(2)} \mathrm{NP}_{\mathrm{i}}^{(3)}$ and $\mathrm{NP}_{\mathrm{i}}^{(4)}$-Ranks of adjusted yield means of genotypes (Thennarasu, 1995).

\section{DISCUSSION}

GEI is a universal phenomenon existing in MEYTs and complicates the selection of superior genotypes (Ebdon and Gauch, 2002; Yan and Kang, 2003). Various methods are used for reducing GEI effects and facilitating genotype characterization, as selection criteria together with the mean yield of the genotypes. Accordingly, genotypes with minimal variance for yield across environments are considered stable. This idea of stability may be considered as a biological or static concept of stability (Becker and Leon, 1988). This concept of stability is not acceptable to most breeders and agronomists, who prefer genotypes with high mean yields and the potential to respond to agronomic inputs or better environmental conditions (Becker, 1981). The high yield performance of released cultivars is one of the most important targets of breeders; therefore, they prefer a dynamic concept of stability (Becker and Leon, 1988).

In our study, the PC1 separated mean yield (Y), TOP, YS, PA and RM (Group 1) from the other NPSSs (Groups 2 and 3) (Figure 1). Based on the concepts of stability, namely the static (biological) and dynamic (agronomical) ones, PC1 distinguished NPSSs that the statistics Y, TOP, YS, PA and RM were related with dynamic stability 
(Group 1) and other remaining methods (Groups 2 and 3) were associated with static stability (Mohammadi et al., 2012). Meanwhile, the highly positive significant correlation between TOP, YS, PA, RM and mean yield (Y) indicated that they were possibly the best NPSSs to be used for identifying higher yielding genotypes. Consequently, any one of these NPSSs would be preferred to select stable and higher yielding genotypes in a breeding program.

Flores et al. (1998) pointed out that the TOP, YS and RM procedures were associated with mean yield (Y) and the dynamic concept of stability. Kang and Magari (1995) found that the YS method was related with high yield performance, and therefore this stability statistic defined stability with dynamic concept. Sabaghnia et al. (2006), Mohammadi et al. (2007), Segherloo et al. (2008) and Yong-Jian et al. (2010) found positive significant correlations between TOP, YS and Y in lentil (L. culinaris L.), durum wheat ( $T$. durum L.), chickpea (C. arietinum L.) and maize (Z. mays L.), respectively. Moreover, significant associations between Y, TOP, YS and PA were indicated by Mohammadi and Amri (2013) in durum wheat ( $T$. durum L.).

The high yield performance of released cultivars is one of the most important breeding objectives; therefore, breeders prefer a dynamic concept of stability (Becker and Leon, 1988). In this research, G10, G4, G15, G9 and G8 had a stable yield performance based on the TOP, YS, PA and RM statistics. We found that the NPSSs of Huehn (1996) $\left(\mathrm{S}_{\mathrm{i}}^{(1)}, \mathrm{S}_{\mathrm{i}}^{(2)}, \mathrm{S}_{\mathrm{i}}^{(3)}\right.$ and $\left.\mathrm{S}_{\mathrm{i}}^{\left({ }^{(6)}\right.}\right)$ and the $\mathrm{NP}_{\mathrm{i}}^{(1)}, \mathrm{NP}_{\mathrm{i}}^{(2)}$, $\mathrm{NP}_{\mathrm{i}}{ }^{(3)}$ and $\mathrm{NP}_{\mathrm{i}}{ }^{(4)}$ of Thennarasu (1995), Ketata's (1988) RSD and YSD and $\mathrm{R}_{1}$ and $\mathrm{R}_{2}$ proposed by Langer et al. (1979) grouped together (Groups 2 and 3 in Figure 1), since these NPSSs classified genotypes as stable or unstable in a similar fashion. Sabaghnia et al. (2006) found positive significant correlations among these NPSSs in lentil (L. culinaris L.). Scapim et al. (2000) also reported positive significant correlations between $\mathrm{S}_{\mathrm{i}}{ }^{(1)}$ and $\mathrm{S}_{\mathrm{i}}{ }^{(2)}$ in maize (Z. mays L.). Flores et al. (1998) revealed high rank correlations between $\mathrm{S}_{\mathrm{i}}{ }^{(1)}$ and $\mathrm{S}_{\mathrm{i}}{ }^{(2)}$ in faba bean ( $V$. faba L.) and pea (P. sativum L.). Nassar and Huehn (1987) reported that $\mathrm{S}_{\mathrm{i}}^{(1)}$ and $\mathrm{S}_{\mathrm{i}}^{(2)}$ were associated with the static (biological) concept of stability, as they define stability in the sense of homeostasis. The stability statistics of $\mathrm{NP}_{\mathrm{i}}^{(4)}, \mathrm{S}_{\mathrm{i}}^{(1)}, \mathrm{S}_{\mathrm{i}}^{(2)}, \mathrm{NP}_{\mathrm{i}}^{(1)}$ and RSD represent static concepts of stability, and are not correlated with mean yield (Y). Therefore, these stability statistics could be used as compromise methods to select genotypes with moderate yield and high stability (Akcura et al., 2009).

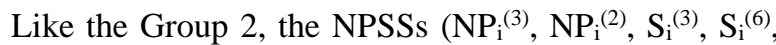
$\mathrm{R}_{1}$, YSD and $\mathrm{R}_{2}$ ) from Group 3 identified genotypes that were stable based on the static or biological concept of stability, but unlike Group 2, they were also strongly negatively correlated with high mean yield (Y). This concept of stability is not acceptable to most breeders and agronomists, who prefer genotypes with high mean yields and the potential to respond to agronomic inputs or better environmental conditions (Becker, 1981). For example, genotypes G5, G7 and G11 had stable yield performance but had low mean yield based on the NPSSs from Group 3 in our study. Therefore, we do not recommend use of these NPSSs for genotype selection. Mohammadi et al. (2007) and Yong-Jian et al. (2010) reported that the NPSSs $\mathrm{S}_{\mathrm{i}}{ }^{(3)}, \mathrm{S}_{\mathrm{i}}{ }^{(6)}, \mathrm{NP}_{\mathrm{i}}{ }^{(2)}, \mathrm{NP}_{\mathrm{i}}{ }^{(3)}$ and $\mathrm{NP}_{\mathrm{i}}{ }^{(4)}$ were not suitable for detecting stable and high yielding genotypes.

\section{CONCLUSION}

Our study indicated that group 1 (TOP, YS, PA and RM with yield mean) NPSSs can be used as selection criteria in a breeding program for detecting higher yielding and stable genotypes tested in MEYTs. With respect to 16 NPSSs used in the current study, G15 was the most stable and third highest yielding genotype. However, it was an officially registered cultivar. G5 and G7 were the most stable ones among the all advanced lines tested, but their yield performances were lower. As a consequence, this study underlined that the crossing block of TNDWBP should be enhanced by germplasm carrying genes determining wide adaptation and higher yielding ability.

\section{ACKNOWLEDGMENTS}

This study was supported by the Ministry of Food, Agriculture and Livestock, Republic of Turkey, Project No: TAGEM/TBAD/13/A12/P05/005.

\section{LITERATURE CITED}

Akcura, M., Y. Kaya and S. Taner. 2009. Evaluation of durum wheat genotypes using parametric and nonparametric stability statistics. Turk. J. Field Crops, 14(2): 111-122.

Becker, H.C. 1981. Correlations among some statistical measures of phenotypic stability. Euphytica, 30: 835-840.

Becker, H.C. and J. Leon. 1988. Stability analysis in plant breeding. Plant Breed. 101: 1-23.

Duarte, B.J. and M.J.O. Zimmermann. 1995. Correlation among yield stability parameters in common bean. Crop Sci. 35: 905-912.

Ebdon, J.S. and H.G. Gauch. 2002. Additive main effects and multiplicative interaction analysis of National Turfgrass performance trials: II. Genotype recommendation. Crop Sci. 42: 497-506.

Flores, E., M.T. Moreno and J.I. Cubero. 1998. A comparison of univariate and multivariate methods to analyze environments. Field Crop Res. 56: 271-286.

Fox, P.N., B. Skovmand, B.K. Thompson, H.J. Braun and R. Cormier. 1990. Yield and adaptation of hexaploid spring triticale. Euphytica, 47: 57-64.

Habash, D.Z., Z. Kehel and M. Nachit. 2009. Genomic approaches for designing durum wheat ready for climate change with a focus on drought. J Exp Bot 60(10): 28052815.

Huehn, M. 1979. Beitrage zur Erfassung der phanotypischen Stabilitat. EDV Med. Biol 10:112-117.

Huehn, M. 1990. Nonparametric measures of phenotypic stability: I. Theory. Euphytica, 47: 189-194.

Huehn, M. 1996. Non-parametric analysis of genotype $\mathrm{x}$ environment interactions by ranks. In: Genotype by Environment Interaction, ed. Kang, M.S. and Gauch J.H.G., 235-271, CRC. FL.

Hussein, M.A., A. Bjornstad and A.H. Aastveit. 2000. SASG x ESTAB: A SAS program for computing genotype $x$ environment stability statistics. Agron J 92: 454-459. 
Kang, M.S. 2002. Genotype-Environment Interaction: Progress and Prospects. In: Quantitative genetics, genomics and plant breeding. ed. Kang, M.S. 221-243. CAB.

Kang, S.M. and R. Magari. 1995. STABLE: A BASIC program for calculating stability and yield-stability statistics. Agron J 87: 276-277.

Ketata, H. 1988. Genotype $\mathrm{x}$ environment interaction. Proceeding of the workshop on biometrical techniques for cereal breeders. 16-32, ICARDA, Aleppo, Syria.

Langer, S., K.J. Frey and T. Baily. 1979. Association of different stability models in wheat. Euphytica, 28: 17-24.

Lipkovich, I.A. and E.P. Smith. 2002. Biplot and Singular Value Decomposition Macros for ExcelC. J Stat Softw 7(5):1-15.

Lu, H.S. 1995. PC-SAS Program for estimating Huhn's nonparametric stability statistics. Agron J 87: 888-891.

Mohammadi, R., A. Abdulahi, R. Haghparast and M. Armion. 2007. Interpreting genotype $\mathrm{x}$ environment interactions for durum wheat grain yields using non-parametric methods. Euphytica, 157: 239-251.

Mohammadi, M., R. Karimizadeh, N. Sabaghnia and M. K. Shefazadeh. 2012. Genotype $\times$ environment interaction and yield stability analysis of new improved bread wheat genotypes. Turk J Field Crops, 17 (1): 67-73.

Mohammadi, R. and A. Ahmed. 2013. Genotype x environment interaction and genetic improvement for yield and yield stability of rain-fed durum wheat in Iran. Euphytica, 192: 227-249.

Nassar, R. and M. Huehn. 1987. Studies on estimation of phenotypic stability: tests of significance for nonparametric non-parametric measures of phenotypic stability. Biometrics, 43: 45-53.

Nesbitt, M. And D. Samuel. 1996. From staple crop to extinction? The archaeology and history of hulled wheat. In: Hulled Wheats. ed. Padulosi, S., K. Hammer and J. Heller. 40-99. IPGRI.
Royo, C., M.E. Elias and F.A. Manthey. 2009. Durum Wheat Breeding. In: Cereals. ed. Carena, M.J. 199-226. Springer.

Sabaghnia, N., H. Dehghani and S.H. Sabaghpour. 2006. Nonparametric methods for interpreting genotype $\mathrm{x}$ environment interaction of Lentil genotypes. Crop Sci. 46: 1100-1106.

Scapim, C.A., V.R. Oliveira, A.L. Braccinil, C.D. Cruz, C.A.B. Andrade and M.C.G. Vidigal. 2000. Yield stability in maize (Zea mays L.) and correlations among the parameters of the Eberhart and Russell, Lin and Binns and Huehn models. Genet Mol Biol 23: 387-393.

Segherloo, A.E., S.H. Sabaghpour, H. Dehghani and M. Kamrani. 2008. Non-parametric measures of phenotypic stability in chickpea genotypes (Cicer arietinum L.). Euphytica, 162: 221-229.

Shukla, G.K. 1972. Some aspects of partitioning genotypeenvironmental components of variability. Heredity, 28: $237-$ 245.

St-Pierre, C.A., H.R. Klinck and F.M. Gauthier. 1967. Early generation selection under different environments as it influences adaptation of barley. Can J Plant Sci. 47: 507-517.

Thennarasu, K. 1995. On certain non-parametric procedures for studying genotype-environment interactions and yield stability. PJ School, IARI, New Delhi, India. PhD Diss.

Yan, W. and M.S. Kang. 2003. GGE biplot analysis: a graphical tool for breeders, geneticists, and agronomists. CRC Press, Boca Raton.

Yildirim, A., O.A. Sonmezoglu, A. Sayaslan, M. Koyuncu, T. Gulec and N. Kandemir. 2013. Marker-assisted breeding of a durum wheat cultivar for $\gamma$-gliadin and LMW-glutenin proteins affecting pasta quality. Turk J Agric For 37: 527 533.

Yong-jian, L., D. Chuan, T. Meng-liang, H. Er-liang and H. Yubi. 2010. Yield stability of maize hybrids evaluated in maize regional trials in southwestern China using nonparametric methods. Agric Sci China 9 (10): 1413-1422. 